\title{
SOME PHYSIOLOGICAL CHANGES IN WALDSTEINIA TRIFOLIA (ROCH.) LEAVES IN DIFFERENT MONTHS OF THE YEAR
}

\author{
Renata Wojciechowska ${ }^{1}$, Tadeusz Kobyłko ${ }^{2}$, Anna Hostyńska ${ }^{2}$ \\ ${ }^{1}$ Department of Plant Physiology, ${ }^{2}$ Department of Botany, Faculty of Horticulture, Agricultural University in Kraków, \\ 29 Listopada 54, 31-425 Kraków, Poland \\ e-mail: rwojciechowska@bratek.ogr.ar.krakow.pl
}

Received: 2.10 .2008

S u m m a r y

The study concerned an evergreen herbal plant Waldsteinia trifolia Roch. This species can be found more and more often in garden plantings in Poland. The aim of the study was to estimate the content of photosynthetic pigments, anthocyanins and dry matter as well as the permeability of cytoplasmatic membranes of Waldsteinia leaves. Plants grew in an ornamental plant collection at the premises of the Faculty of Horticulture of the Agricultural University in Kraków. The study was conducted in 2006 and 2007 in the following months: March, May, June, September, October and November. The permeability of cytoplasmatic membranes was estimated based on electrolyte leakage from leaf discs at $20^{\circ} \mathrm{C}$ in relation to total electrolytes in the tissue after unfreezing. The first days with temperature drops down to around $0^{\circ} \mathrm{C}$ in autumn resulted in a decrease in chlorophyll $a, b$ and carotenoid content, but significantly increased anthocyanin content. The ratio of chlorophyll $a$ to $b$ and the ratio of total chlorophylls to carotenoids did not change in particular months. In both years of study, similar changes in dry matter content of the Waldsteinia leaves were observed. Dry matter content significantly increased in June and November and decreased in May and October. In June and in autumn, after first slight frosts, an increase of electrolyte leakage from the leaf discs was observed. However, high dry matter content (40.3\%) was accompanied by lower permeability of the cytoplasmatic membranes of the leaves after winter during March. These results have shown good adaptation of Waldsteinia trifolia plants to the climatic conditions in Poland.

Key words: chlorophyll $a, b$, carotenoids, anthocyanins, electrolyte leakage, dry matter

\section{INTRODUCTION}

Poland is situated in the moderate climate zone, transitional between the maritime and continental climates. Compared to western and southern Europe countries, frosty winters, periodically occurring here, or non-typical warmings in January or February, or else large temperature drops in November and March, create certain limitations for a greater selection of plant species. In addition, in spring and summer months air temperature quite frequently exceeds $30^{\circ} \mathrm{C}$. Such weather variability, but also large diurnal temperature fluctuations, which sometimes occur, may cause disturbances in the growth and development of plants, including evergreen plants. Leaves of these plants, living several years on average, are characterised by specific physiological activity associated, for example, with the annual course of photosynthesis. It has been demonstrated that, compared to deciduous plants, evergreen plants have higher nutrient use efficiency, a lower rate of nutrient removal from older leaves, a higher lignin content, and leaf life span is negatively correlated with the maximum rate of photosynthesis, nitrogen concentration in leaves and their specific surface area (A e r ts , 1995). Available studies on the physiology of evergreen plants primarily relate to trees and shrubs (Czekalski, 1986; Oliveira and Penuelas, 2000; W a r r e $\mathrm{n}$ and A d a m s , 2004). Waldsteinia trifolia belongs to few herbaceous plants which do not lose leaves in the conditions of Poland.

Waldsteinia trifolia Roch., syn. Waldsteinia ternata (Stephan) Fritsch syn. Dalibarda ternata Stephan, belongs to the family Rosaceae - the rose family. It is recognised to be a representative of pre-glacial ArcticTertiary flora which survived in specific refuges, inter alia, in Europe on the southern side of the Carpathian Mountains in deep, moist, shady ravines (M a g i c, 1959; Z a hradnikova, 1992). Due to its relic nature and rare occurrence resulting from its small competitive potential, it has the status of a protected plant included in the Red Books ( $\mathrm{Mag}$ i c and Ferako$\mathrm{v}$ a ). It does not occur in a natural state in Poland. It is a perennial plant with a creeping, branched rhizome, trifoliate leaves, yellow flowers clustered in groups of 3-7 borne on erect stems $10-15 \mathrm{~cm}$ high. Its original, 
mat-forming habit, rich lively green and evergreen foliage, abundant and quite long flowering make this species to be considered an attractive ornamental plant, and for some time it has also been included in offers of Polish horticultural firms.

The aim of the study was to estimate, in some months of the year, the content of photosynthetic pigments, anthocyanins and dry matter as well as the permeability of cytoplasmatic membranes of the leaves of Waldsteinia trifolia, little known in terms of its physiology.

\section{MATERIALS AND METHODS}

Waldsteinia trifolia plants growing at the premises of the Faculty of Horticulture of the Agricultural University in Kraków were the object of the study. The investigations were conducted in the years 2006 and 2007 at six dates which were the following, respectively: 27 March (in both years), 14 and 11 May, 13 June (in both years), 25 and 22 September, 25 and 20 October as well as 22 and 23 November. For the purpose of simplification, in the further part of the present paper only names of the respective months are given.

On each date of analysis, about 30 grams of fullydeveloped, not ageing leaves were sampled; they were always collected from the middle portion of the stem. The leaves were carefully rinsed first in running water, and then twice in distilled water. After drying them with filter paper, 2-4 discs were excised from each leaf between the veins using a cork borer. 6 discs were selected by random sampling from each representative group so prepared in five replications; they were weighed, placed in test tubes and immersed in $15 \mathrm{~cm}^{3}$ of distilled water. After 24 hours of incubation in the dark at a temperature of $20^{\circ} \mathrm{C}$, measurements of specific conductivity were made in the obtained diffusate using a conductometer OK-102/1. Next, each sample with the discs was frozen for a period of 48 hours at $-18^{\circ} \mathrm{C}$ and, after unfreezing and bringing the respective sample to a temperature of $20^{\circ} \mathrm{C}$, specific conductivity of the solution was measured again. This measurement allowed the calculation of the percentage share of electrolytes diffused after 24 hours in their total amount in the tissue.

The remaining discs of the representative sample were used for the determination of the content of photosynthetic pigments and anthocyanins as well as of dry matter. After grinding the samples, weighed portions of $0.5 \mathrm{~g}$ were prepared in order to determine the chlorophyll and carotenoid content, and separately - the anthocyanin content. The chlorophyll 'a', 'b' and carotenoid content was determined and calculated using the method and formulas described in a paper by Wellburn (1994). The anthocyanin pigments were determined following the method of Murray and $\mathrm{H}$ a c k e $t \mathrm{t}$ (1991). Under this method, the absorbance was read at two wave lengths, taking into account the maximum absorbance for anthocyanins $(536 \mathrm{~nm})$ and chlorophylls masking them $(653 \mathrm{~nm})$. Both values were presented in charts. The analysis of the content of photosynthetic pigments and of anthocyanins was performed in four replications.

In order to determine dry matter, $1 \mathrm{~g}$ portions were weighed in three replications, which were then dried to constant weight at a temperature of $105^{\circ} \mathrm{C}$.

Statistical analysis of the results was carried out for each year separately using the STATISTICA programme by means of Fisher's LSD test, at $\mathrm{p}=0.05$.

\section{RESULTS AND DISCUSSION}

The content of photosynthetic pigments in the Waldsteinia leaves changed depending on the year and date of analysis (Fig. 1). The highest level of chlorophylls $a, b$ and carotenoids was found in 2007 in May and June. But in 2006 the content of the pigments in question was the highest in September, which might have been caused by favourable weather conditions that occurred after a relatively cool spring and hot summer in that year (Figs 3 and 4). In the next months, together with temperature drops, the amount of pigments gradually decreased. In September 2007 over $30 \%$ less chlorophylls and carotenoids were noted in the Waldsteinia leaves compared to the May and June dates. The reason for this phenomenon could be the first temperature drops down to around $0^{\circ} \mathrm{C}$ which occurred just before the September date of analysis (Fig. 4). This level was maintained throughout autumn. In available literature, there is little data on the content of photosynthetic pigments in leaves of evergreen plants. The results relating to chlorophyll content obtained in the present study are similar to those shown in winter-deciduous leaves (B o a r d m a n, 1977). But it has been proved that lower photosynthetic activity in evergreen leaves is associated with a lower level of involvement of RUBISCO enzyme in $\mathrm{CO}_{2}$ assimilation (Warren and A d a m s, 2004).

It is interesting that the ratio of chlorophyll $a$ to $b$ in the Waldsteinia leaves on all the dates and in all the years of study was relatively constant and it was $3.5: 1$, on the average. Also, no great changes were observed in the proportions between green and yellow pigments, which usually change in autumn in winterdeciduous leaves (H o s ty ń s k a et al. 2007). But the discolourations of the Waldsteinia leaves were associated with the content of anthocyanin pigments (Fig. 2). In 2006 the increased synthesis of anthocyanins started in October when temperature dropped below $5^{\circ} \mathrm{C}$, but there was no ground frost (Fig. 4). Until November temperature fluctuations within a similar range fur- 
ther stimulated the synthesis of these pigments. The obtained results have confirmed the view that cool autumn nights, but without ground frost, promote the increase in anthocyanin content in leaves ( $\mathrm{L}$ e a r, 1986; Pietrini, 2002). A similar situation existed in the year 2007 in which night temperatures of about $5^{\circ} \mathrm{C}$ promoted a significant increase in anthocyanin content in the Waldsteinia leaves already in September. Over a double increase occurred in October, but after a period of several days with subzero temperature in November (down to $-5.7^{\circ} \mathrm{C}$ ), there was a significant decline. It is worth noting that also on the March date of analysis temperatures closer to $0^{\circ} \mathrm{C}$ promoted the synthesis of these pigments. There were more anthocyanins in this month with mean temperature of $2.44^{\circ} \mathrm{C}$ in 2006 than in the year 2007 when mean temperature in March was $7.73^{\circ} \mathrm{C}$. The role of anthocyanins in leaves has been the subject of many studies (G o u ld et al., 2000; Hoch et al., 2003). Anthocyanins absorb blue-green light, protecting chlorophyll pigments against high-energy light waves. G o u l d et al. (2002) have demonstrated that in the red leaves of Quintinia serrata they are present in the upper epidermis, performing the function of light filter for the lower located mesophyll cells. As a result of that, photosynthesis in the red leaves is less intensive and it is similar to that occurring in shade plants. The results obtained in the present study show that plants increase the synthesis of anthocyanins at temperatures close to $0^{\circ} \mathrm{C}$, which are often accompanied by photooxidative stress in our climate. Due to this protective function, photosynthesis may take place in evergreen leaves on cool sunny days without major obstacles, although at a lower level.

Damage in plant cells exposed to stress factors relates in the first place to cytoplasmatic membranes. A good indicator of this type of damage is the measurement of electrolyte leakage from plant tissue ( $\mathrm{S} \mathrm{ta} \mathrm{r} \mathrm{k}$ et al. 1995; $\mathrm{F} \mathrm{u}$ et al. 2006). When analysing the share of electrolytes which diffused from the Waldsteinia leaf discs over a period of 24 hours in total electrolytes in the tissue, it can be stated that in 2006 the cell membranes were characterized by the greatest permeability on the June date as well as in November and March, whereas in 2007 - in November and then in June (Tab. 1). The increase in electrolyte leakage in both years in the month of June confirms that the cytoplasmatic membranes in young cells are characterized by greater sensitivity compared to cells in which the growth is finished and which have achieved greater resistance to stress factors, including higher temperatures (Fig. 3). But the marked increase in electrolyte leakage from the tissues demonstrated in November, in particular in 2007, shows the destructive effect of quite large temperature drops which occurred over this

Table 1

Electrolyte leakage from Waldsteinia leaf discs, depending on the year and month of the study, expressed as the percentage of total electrolytes in the tissue.

\begin{tabular}{cccccccc}
\hline $\begin{array}{c}\text { Date of } \\
\text { analysis }\end{array}$ & March & May & June & September & October & November & $\begin{array}{c}\text { Annual } \\
\text { mean }\end{array}$ \\
\hline 2006 & $19.06 \mathrm{~d}$ & $9.22 \mathrm{a}$ & $20.82 \mathrm{e}$ & $14.46 \mathrm{~b}$ & $17.58 \mathrm{c}$ & $20.24 \mathrm{de}$ & 16.90 \\
\hline 2007 & $22.56 \mathrm{c}$ & $23.32 \mathrm{c}$ & $26.28 \mathrm{~d}$ & $18.78 \mathrm{~b}$ & $15.18 \mathrm{a}$ & $28.97 \mathrm{e}$ & 22.51 \\
\hline $\begin{array}{c}\text { Monthly } \\
\text { mean }\end{array}$ & 20.81 & 16.27 & 23.55 & 16.62 & 16.38 & 21.75 & 19.70 \\
\hline
\end{tabular}

${ }^{1}$ Values designated with the same letters do not differ significantly

Table 2

Dry matter content in Waldsteinia leaves depending on the date of analysis (\%).

\begin{tabular}{cccccccc}
\hline $\begin{array}{c}\text { Date of } \\
\text { analysis }\end{array}$ & March & May & June & September & October & November & $\begin{array}{c}\text { Annual } \\
\text { mean }\end{array}$ \\
\hline 2006 & $40.8 \mathrm{abc}^{1}$ & $36.9 \mathrm{a}$ & $44.5 \mathrm{c}$ & $39.9 \mathrm{abc}$ & $37.0 \mathrm{a}$ & $41.9 \mathrm{bc}$ & 40.2 \\
\hline 2007 & $39.9 \mathrm{abc}$ & $39.6 \mathrm{abc}$ & $42.2 \mathrm{c}$ & $38.8 \mathrm{ab}$ & $38.2 \mathrm{a}$ & $42.0 \mathrm{bc}$ & 40.1 \\
\hline $\begin{array}{c}\text { Monthly } \\
\text { mean month }\end{array}$ & 40.3 & 38.3 & 43.4 & 39.3 & 37.6 & 42.0 & 40.1 \\
\hline
\end{tabular}

${ }^{1}$ Values designated with the same letters do not differ significantly 


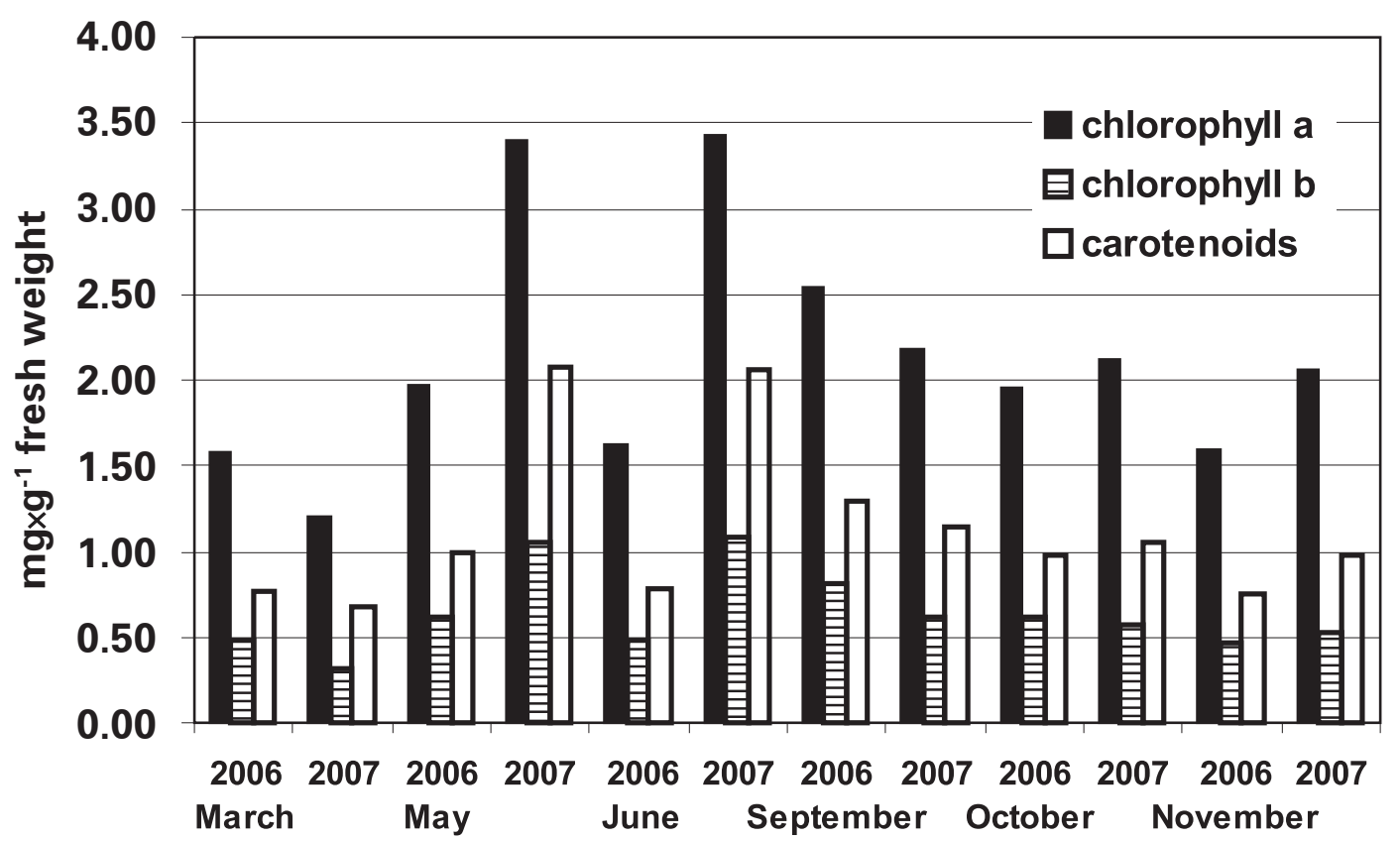

Fig. 1. Chlorophyll $a, b$ and carotenoid content in Waldsteinia trifolia leaves in some months of the years 2006-2007.

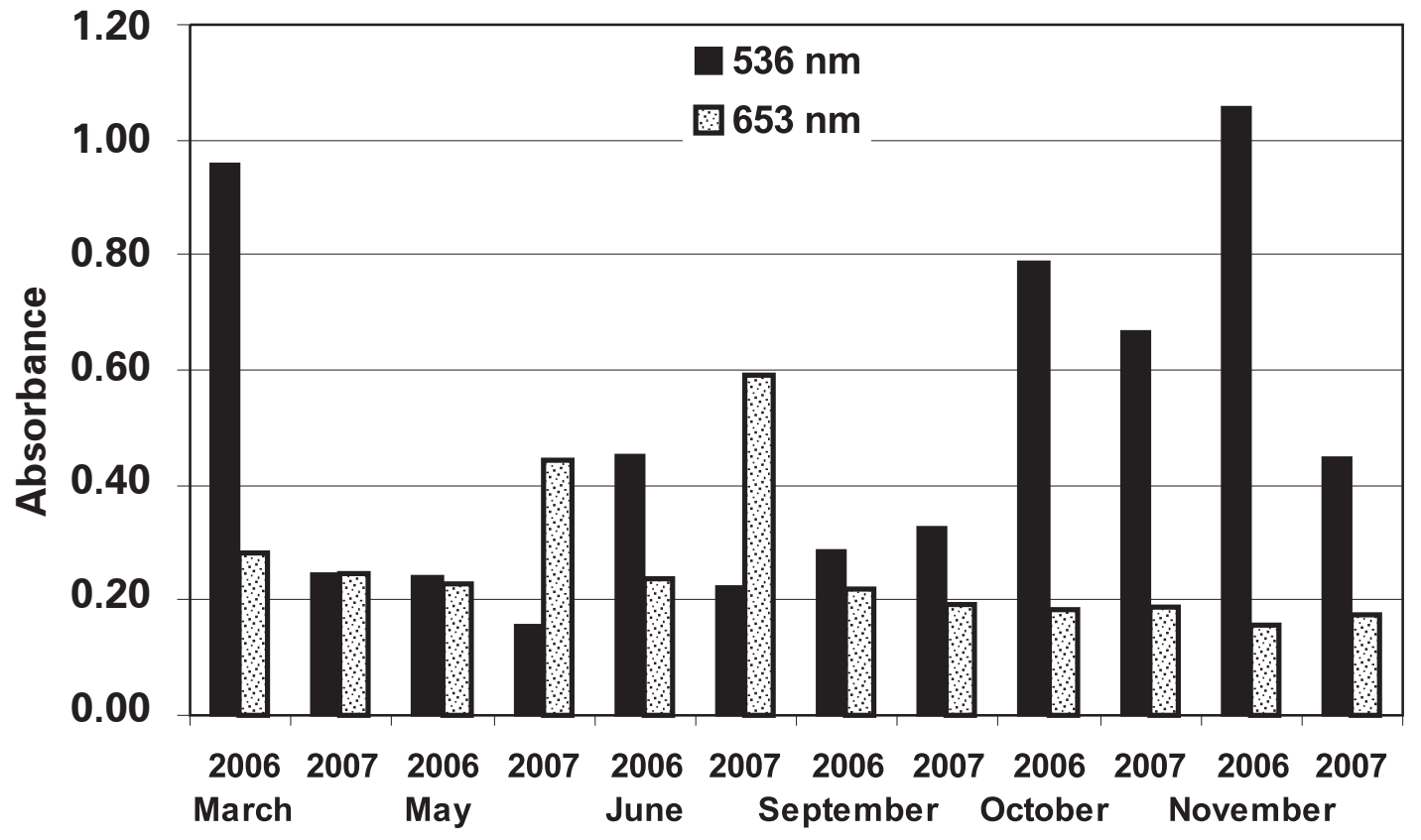

Fig. 2. Light absorbance by anthocyanins $(536 \mathrm{~nm})$ and chlorophylls $(653 \mathrm{~nm})$ contained in extracts of Waldsteinia trifolia leaves in some months of the years 2006-2007. 




Fig. 3. Mean monthly air temperatures in the years 2006-2007.



Fig. 4. Air temperature from 1 September to 30 November in the years 2006-2007 (the absence of line continuity results from not complete meteorological data). 
period (Fig. 4). The smallest degree of damage of the cell membranes was demonstrated in May 2006. This result is difficult to interpret. Perhaps, after a relatively cool spring in this year which slowed down the growing process, a larger amount of older leaves was sampled for analysis.

Dry matter content in the Waldsteinia trifolia leaves was high at each date of study and it was above $40 \%$, on the average (Tab. 2). In both years, similar changes in dry matter content were observed, which were manifested in a distinct increase on the June date, most probably as a result of intensified production of assimilates, as well as on the November date, when the plants were preparing for the winter period. In leaves of evergreen plants, dry matter content is usually much higher than in winter-deciduous leaves (A e r t s , 1995). They have more secondary compounds making up the cell wall, such as lignin, which, by strengthening the secondary cell wall, increase cell resistance to any damage, including freezing.

It is interesting that on the March date the Waldsteinia trifolia leaves were still characterised by very high dry matter content. It is also worth noting that on that date electrolyte leakage from the leaves was at an average level, and even in 2007 it was similar to that demonstrated in the month of May (Tab. 1). These data confirm that this species has adaptations characteristic of Arctic vegetation and it is suitable for plantings in Poland, even in regions with large temperature drops.

\section{CONCLUSIONS}

1. The content of photosynthetic pigments in the Waldsteinia leaves changed depending on the date of analysis, but the proportions of chlorophyll $a$ to $b$ and of chlorophylls to carotenoids did not change.

2. The Waldsteinia leaves accumulated the largest amount of anthocyanins in the months in which cool temperatures occurred without ground frost.

3. The cytoplasmatic membranes were characterised by the greatest permeability in June and in autumn, after the occurrence of first ground frosts.

4. Dry matter content in the Waldsteinia leaves was from 36.9 to $44.5 \%$, and it was the highest in both years of study in June and November.

\section{REFERENCES}

Aerts R., 1995. The advantages of being evergreen. Tree, 10 (10): 402-407.

Boardman N. K., 1977. Comparative photosynthesis of sun and shade plants. Ann. Rev. Plant Physiol. 28: 355-377.

Czekalski A., 1986. Zimozielone krzewy ozdobne. / Evergreen ornamental plants. PWN, Warszawa.
Fu X., Chang J., An L., Zhang M., Xu S., Chen T., Liu Y., Xin H., Wang J., 2006. Association of the coldhardiness of Chorispora bungeana with the distribution and accumulation of calcium in the cells and tissues. Environm. Exp. Bot. 55: 282-293.

Gould K. S., Markham K. R., Smith R. H., Goris J. J., 2000. Functional role of anthocyanins in the leaves of Quintinia serrata A. Cunn. J. Exp.Bot. 51 (347): 11071115.

Gould K. S., Vogelmann T. C., Han T., Clearwater M.J., 2002. Profiles of photosynthesis within red and green leaves of Quintinia serrata. Physiol. Plant. 116: 127133.

Hoch W. A., Singsaas E. L., Mc Cow n B. H., 2003. Resorption Protection. Anthocyanins felititate nutrient recovery in autumn by shelding leaves from potentially damaging light levels. Plant Physiol. 133: 1296-1305.

Hostyńska A., Perzanowska A., Wojciechowska R., 2007. Zmiany zawartości różnych barwników w liściach wybranych gatunków drzew i krzewów w okresie jesiennym. / Changes in the content of different pigments in leaves of selected tree and shrub species in the autumn period. Zesz. Nauk. AR Kraków, 444 (93): 263-269.

Lear B.,1986. Autumn leaves. ChemMatters, October: 1-7.

Magic D., 1959. Vegetacne a fytogeograficke pomery novych lokalit waldsteinie trojlistej (Waldsteinia trifolia Roch.) na slovensku. Biologicke prace. Vydavatelstvo Slovenskej Adademie Vied v Bratislave V/10: 5-31.

Magic D., Ferakova V., Cervena Kniha 5. Vyssie rastliny: 408.

Murray J. R., Hackett W. P., 1991. Dihydroflavonol reductase activity in relation to differential anthocyanin accumulation in juvenile and mature phase Hedera helix L. Plant Physiol. 97: 343-351.

Oliveira G., Penuelas J., 2000. Comparative photochemical and phenomorphological responses to winter stress of an evergreen (Quercus ilex L.) and a semi-deciduous (Cistus albidus L.) Mediterranean woody species. Acta Oecologica, 21 (2): 97-107.

Pietrini F., 2002. Anthocyanin accumulation in the illuminated surface of maize leaves enhances protection from photo-inhibitory risks at low temperature without further limitation to photosynthesis. Plant Cell Environ. 25: 1251-1305.

Starck Z., Chołuj D., Niemyska B., 1995. Fizjologiczne reakcje roślin na niekorzystne czynniki środowiska. / Physiological responses of plants to adverse environmental factors. SGGW, Warszawa.

Warren C. R., Adams M. A., 2004. Evergreen trees do not maximize instantaneous photosynthesis. Trends in Plant Sci. 9(6): 1360-1385.

Wellburn A. R., 1994. The spectral determination of chlorophylls $a$ and $b$, as well as total carotenoids, using various solvents with spectrophotometers of different resolution. J. Plant Physiol. 144: 307-313.

Zahradnikova K., 1992. Waldsteinia Wild. [W]: Flora Slovenska IV/3. Wyd. VEDA. Bratislava: 131-137. 


\section{Wybrane zmiany fizjologiczne w liściach waldsteinii trójlistkowej (Waldsteinia trifolia Roch.) w różnych miesiącach roku}

\section{Streszczenie}

Obiektem badań była waldsteinia trójlistkowa (Waldsteinia trifolia Roch.), należąca do zimozielonych roślin zielnych. Gatunek ten coraz częściej można spotkać w nasadzeniach ogrodowych w Polsce. Celem pracy było zbadanie zawartości barwników asymilacyjnych, antocyjanów, suchej masy oraz przepuszczalności błon cytoplazmatycznych w liściach waldsteinii, rosnącej w kolekcji roślin ozdobnych przy Wydziale Ogrodniczym Uniwersytetu Rolniczego w Krakowie w następujących miesiącach: marcu, maju, czerwcu, wrześniu, październiku i listopadzie. Badania przeprowadzono w latach 2006 i 2007. Przepuszczalność błon cytoplazmatycznych oceniono na podstawie wycieku elektrolitów z krążków liściowych po inkubacji w tem- peraturze $20^{\circ} \mathrm{C} \mathrm{w}$ stosunku do całkowitej ich ilości $\mathrm{w}$ tkance po rozmrożeniu.

Jesienne spadki temperatur bliskie $0^{\circ} \mathrm{C}$ wpływały na zmniejszenie zawartości chlorofilu $a, b$ i karotenoidów oraz na istotne zwiększenie zawartości antocyjanów w liściach waldsteinii. Wykazano, że stosunek chlorofilu $a$ do $b$ oraz chlorofili do karotenoidów w badanych liściach był względnie stały w poszczególnych miesiącach badań. Zaobserwowano podobne w obu latach zmiany $\mathrm{w}$ zawartości suchej masy $\mathrm{w}$ liściach waldsteinii tj. wyraźny wzrost $\mathrm{w}$ terminie czerwcowym oraz listopadowym, a spadek w maju i październiku. Wzrost wycieku elektrolitów w dyfuzacie z krążków liściowych obserwowano w terminie czerwcowym oraz jesienią po wystapieniu pierwszych przymrozków. Natomiast po zimie wysokiej zawartości suchej masy $(40,3 \%)$ towarzyszyła mniejsza przepuszczalność błon cytoplazmatycznych, co wskazuje na dobre przystosowanie roślin waldsteinii do warunków klimatycznych w Polsce. 